\title{
The role of brand image in consumer-brand relationships: similarities and differences between national and private label brands
}

\author{
Adi ALIĆ \\ University of Sarajevo, Sarajevo, Bosnia and Herzegovina \\ Merima ČINJAREVIĆ \\ University of Sarajevo, Sarajevo, Bosnia and Herzegovina \\ merima.cinjarevic@efsa.unsa.ba \\ Emir AGIĆ \\ University of Sarajevo, Sarajevo, Bosnia and Herzegovina
}

\begin{abstract}
The purpose of the present research is to explore the effect of brand image on brand loyalty and brand commitment to national and private label brands. Data was collected through a field survey via the store-intercept method. To test the research hypotheses, we used two samples, which implied the collection of usable 528 questionnaires. Confirmatory factor analysis was used to test the reliability, convergent, and discriminant validity of the constructs of interest. The structural equation modeling (SEM) technique was employed to analyze the effect of brand image on brand loyalty and brand commitment. Also, group comparisons were made between national brands and private label brands, using structural equation modeling. This study reveals that brand image has a significant positive effect on brand loyalty and brand commitment, both for national and private label brands. Moreover, it was found that the effect of brand image on brand commitment is stronger for national brands than for private label brands. The present study provides marketing managers of national brands and private label brands some insights into how to spur brand loyalty and commitment by establishing a favorable brand image.
\end{abstract}

Keywords: Brand image, Brand loyalty, Brand commitment, National brand, Private label brand

Please cite the article as follows: Alić, A., Činjarević, M., \& Agić, E. (2020), "The role of brand image in consumer-brand relationships: similarities and differences between national and private label brands", Management \& Marketing. Challenges for the Knowledge Society, Vol. 15, No. 1, pp. 1-16. DOI: $10.2478 /$ mmcks-2020-0001.

\section{Introduction}

The battle between national brands (hereafter NBs) and private label brands (hereafter PLBs) has been intensified dramatically over the past few decades (Cuneo et al., 2019; Juhl et al., 2006). Recognizing the benefits of private branding such as higher retail margins, increased in-store traffic, stronger negotiating position with manufacturers, an opportunity to build retailer image, and customer loyalty, retailers have started to develop their own brands within and across product categories (Baltas \& Argouslidis, 2007). Sitting side by side on retailer's shelves, NBs and PLBs are "strange bedfellows", who are struggling to capture consumers' hearts and minds. In this recent struggle to conquest the consumers 
from NBs, retailers have placed greater emphasis on the quality of their own brands, and they are striving to build, maintain and strengthen the value or equity of such brands (Cuneo et al., 2019).

PLBs defined as brands controlled and sold exclusively by retailers (Sebri \& Zaccour, 2017), are available in retail stores, and they are ranging from generics, copycats to premium brands (Kumar \& Steenkamp, 2007). The increasing share of PLBs is particularly apparent in the case of consumer-packaged goods where PLBs have experienced a tremendous rise (Cuneo et al., 2019). Market share of PLBs in Europe on average has reached 23\% (Sebri \& Zaccour, 2017), but this share is outpaced in several countries, such as Spain (51\%), Switzerland (49\%), United Kingdom (47\%), Germany (45\%), Belgium (44\%), Austria (43\%) and Portugal (41\%) (PLMA, 2019). Moreover, growth rates for PLBs have surpassed those of NBs (2.5\% versus 1.5\%) (Cuneo et al., 2019). Although the growth of the market share of PLBs in the Southeastern European region (e.g., Bosnia and Herzegovina, Croatia, the Czech Republic, Hungary) was remarkable over the recent years, the relative market share of such brands falls considerably behind that in Western-world. Since PLBs are a relatively new phenomenon in the Southeastern European region, consumers are not acquainted with them and thereby, they may still perceive PLBs as low in quality compared to NBs (Hoskins, 2016; İpek et al., 2016; Sebri \& Zaccour, 2017). Against this background and in light of repeated research calls (e.g., Cuneo et al., 2019; Ipek, 2016; Sebri, \& Zaccour, 2017) to investigate consumer's cognitive and affective responses to PLBs in the PLBs developing markets, the current research is contextualized in the retail sector of Bosnia and Herzegovina.

At the heart of the present study is a concept of the consumer-brand relationship. Consumer-brand relationship refers to the connection between an individual and a brand that is voluntary or enforced interdependently between a brand and an individual (Kumar \& Kaushik, 2020). The extant literature in the marketing field suggests that the developing long-lasting consumer-brand relationship represents the central pillar of marketing success. Indeed, gaining knowledge of how consumers react to brands has been a central topic in marketing literature for decades. Initially, marketing scholars were trying to define and measure consumer cognitive responses to a brand, such as perceived product performance and customer satisfaction. However, during the 1980s and 1990s, the research focus has shifted towards the exploration of long-lasting consumer-brand relationship constructs, such as brand involvement, brand loyalty, brand commitment, and, more recently, brand love and brand fidelity (Grace et al., 2020).

Contemporary marketing literature suggests that consumers can engage in relationships with brands in a way similar to how they relate to human beings (Aggarwal, 2004; Fournier, 1998; Kumar \& Kaushik, 2020). Consumers could express the feelings of love/passion to a particular brand, show the faithfulness to a specific brand, and switch to another brand if consumers' expectations were not met. Driven by the desirable outcomes that can arise from the consumer-brand relationship, companies are finding out the ways of building long-lasting relationships with consumers (Elbedweihy et al., 2016; Ferreira et al., 2019). Despite different possible implications of consumer-brand relationships for NBs and PLBs, only a few studies have explored the ways how consumers develop and maintain these relationships for the NBs as well as PLBs (Garreston et al., 2002; Konuk, 2019; Manzur et al., 2011). Since consumers may have different attitudes toward NBs and PLBs (Garretson et al., 2002; Manzur et al., 2011), it is worthwhile to explore how consumers' 
perceptions of NBs and PLBs are associated to the likeliness of developing strong and favorable bonds between brands and consumers. By identifying whether the effect of brand image on consumer relationships constructs (brand loyalty and brand commitment) is similar or different between NBs and PLBs, the current study provides valuable insights for practitioners who are in a position to design a relationship marketing strategy for NBs and PLBs as well as to guide its implementation.

The present study aims to fill identified gaps and contributes to the literature in the field of branding, particularly the subfield of private branding. Notably, the primary purpose of the present research is to explore the effect of brand image on customer-brand relationship constructs such as brand loyalty and brand commitment. Furthermore, the present study strives to compare the impact of brand image on customer-brand relationship constructs (brand loyalty and brand commitment) among NBs and PLBs. In general, the current research attempts to offer a better understanding of similarities and differences between NBs and PLBs regarding the formation of consumer-brand relationships in the context of PLBs developing markets (for example, the high growth rate of PLBs but the low relative market share of PLBs).

The remainder of the paper is organized as follows. First, we will provide insights into theoretical foundations supporting the research hypotheses. Next, we will describe the research methodology and present analysis and results. In the end, we will provide insight into the main implications, limitations, and future research avenues.

\section{Literature review}

\section{Private label brands versus national brands}

While PLBs are brands owned and sold by retailers under their store brand name or a new brand name, NBs are brands owned and marketed by producers. In general, NBs are wellrecognized brands by the industry and highly popular brands amongst consumers (Wang et al., 2020). On the other hand, PLBs are positioned as substitutes to NBs, rarely achieving the same market success and acceptance by consumers (Wang et al., 2020). Although some retailers offer PLBs which have the same quality or even higher quality than NBs (Akcura et al., 2019), PLBs still have disadvantages over NBs in terms of perceived quality, perceived risk and awareness (Liu et al., 2018). Previous research on PLBs can be divided into four research streams: (1) understanding the strategic role and importance of PLBs for retailers and manufacturers (producers); (2) exploring the market performance of PLBs; (3) examining the differences and competition between NBs and PLBs; and (4) understanding the factors that drive consumers' propensity towards PLBs (Baltas \& Argouslidis, 2007). Prior empirical research that focuses on the comparison between NBs and PLBs pursues two lines: (1) exploring the factors influencing consumer's choice of PLBs over NBs; and (2) examining the competition between NBs and PLBs to identify differentiation and competitive strategies for the manufacturer and the retailer. This last line of the research is our reference point for this study. Specifically, the current research investigates the impact of brand image on consumer-relationship constructs (brand loyalty and brand commitment) for both NBs and PLBs, and, thereby, offers valuable insights for the manufacturer's branding strategy and retailer's PLBs decisions. 


\section{Brand image as a driver of brand loyalty and brand commitment}

The existing brand image literature suggests that a favorable brand image enables companies to build a desired brand's position, enhance the brand's market performance, and shield the brand from competitors (Aaker, 1996). Although the brand image plays a pivotal role in branding, no agreement has yet been reached on its definition and measurement. A broadly accepted view is that a brand image portrays the consumers' perception of a brand (Aaker, 1996) and relates to the set of brand associations retained in consumer's memory (Keller, 1993). Such associations may arise from direct customer experience with a brand or information acquired at the marketplace or as a result of the pre-existing associations about the company (Ogba \& Tan, 2009). Thus, the brand image represents the "mental picture or perception of a brand or a branded product/service and encompasses the symbolic meanings that consumers associate with the specific characteristics of a product/service" (Ogba \& Tan, 2009, p. 133). Prior studies demonstrated that brand image is positively related to consumer satisfaction, consumer trust, and the likelihood of consumer purchases (Nyadzayo \& Khajehzadeh, 2016; Song et al., 2019; Song \& Choi, 2010). Keeping this in mind, brand image is a consumer-based construct, it "helps to understand the attributes, functional consequences, and personal experiences that customers associate with a particular product" (Nyadzayo \& Khajehzadeh, 2016, p. 265). Thus, the brand image plays a pivotal role in the consumer purchase decision process.

\section{Brand image and brand loyalty}

Brand loyalty, as the ultimate goal of the branding process, occurs when the consumer consistently selects a particular brand in the set of available alternatives over a long period, that is, when consumers do not consider any other brands when making a purchase decision. From the initial emergence of the concept to the present day, brand loyalty has had numerous definitions. Regardless of the inconsistency of definitions, brand loyalty represents the vital concept in branding literature.

Aaker (1991) defines brand loyalty as a consumers' attachment to the brand. According to Giovanis and Athanasopoulou (2018, p. 288), brand loyalty refers to the "extent of faithfulness of consumers to a particular brand, irrespective of the marketing activities of competitive brands". Previous research suggests that there are three types of brand loyalty: behavioral, attitudinal, and composite loyalty. Behavioral loyalty refers to consumer's repeated and systematic purchasing behavior for a particular brand. Attitudinal loyalty refers to positive beliefs and feelings toward a specific brand within the set of available alternatives (Dick \& Basu, 1994), that is, a strong internal sympathy of the consumers to the brand (Gounaris \& Stathakopoulos, 2004). Composite loyalty is a concept that integrates behavioral and attitudinal loyalty. One of the earliest proponents of this approach, Day (1969), states that true loyalty includes two facets, namely consumer's repurchase behavior and consumer's positive attitude towards a particular brand.

Previous research confirms the link between brand image and consumer loyalty to the brand. Hsieh et al. (2004) assert that a successful brand image enables consumers to identify the needs that the brand satisfies and differentiate the brand from its competitors, and consequently increases the likelihood that consumers will purchase the brand. Song et al. (2019) argue that brand image can be viewed as a kind of brand performance in consumers' minds, and, thereby, it plays a crucial role in consumer decision making. 
Although some studies have focused on exploring this relationship in the context of NBs (e.g., Bilgihan, 2016; Jing et al., 2014; Ogba \& Tan, 2009), there is a paucity of research regarding the effect of brand image on consumer loyalty to PLBs (Calvo-Porral et al., 2013). Thus, this study proposes:

H1: Brand image has a positive and direct effect on brand loyalty.

\section{Brand image and brand commitment}

In the marketing literature, it is well-established that brand commitment represents the relationship between the consumer and the brand. However, there is an on-going debate regarding the nature of this relationship. One argument is that commitment is an instrumentally based exchange relation among two parties that reflects "an enduring desire to maintain a value of relationship" (Moorman et al., 1992, p. 316). For instance, Morgan and Hunt (1994) argue that commitment is a central concept of relationship marketing. According to Morgan and Hunt (1994), the relationship commitment exists when an exchange partner determines that a current relationship with another is important enough to deserve as much effort as possible to maintain it. In line with this, the committed party believes that it is worthwhile to work on the relationship to ensure it goes on in the long term. Bozzo et al. (2003) indicated that the committed consumer is willing to make short term sacrifices to protect the durability of his/her long-term relationship with a brand. Another school of thought suggests that commitment reflects the economic and affective attachment that a consumer may have towards a particular brand (Iglesias et al., 2011). More recently, scholars have adopted a three-dimensional framework of brand commitment, initially developed by Allen and Meyer (1990) in the domain of organizational science. According to this framework, brand commitment encompasses three dimensions namely, affective, calculative, and normative commitment. The affective commitment refers to consumer's desire to maintain a relationship with a company or buy the product because she/he is sincerely committed to it (Shukla et al., 2016). The calculative commitment represents a constraint-based bonding between a consumer and a company or a brand (Bansal et al., 2014). The calculative commitment arises from the consumer's belief that she/he has to stay in a relationship with a company (brand) due to the lack of available alternatives. Normative commitment depicts the relationship that is based on the consumer's feelings that she/he ought to maintain a relationship with the company or a brand (Bansal et al., 2004). The subjective norms held by consumers profoundly shape normative commitment. The various perspectives and definitions adopted by marketing scholars would lead us to conclude that customer commitment entails at least two components - affective and calculative (Giovanis, 2016; Gundlach et al., 1995). In the present study, brand commitment is operationalized as two-component constructs, including both affective and calculative facets.

As Aaker (1991) suggests, it can be argued that a strong brand with high equity will have a large number of committed customers, leading to high and continuing interaction and communication between the customer and the market offering of the brand. Also, Ogba and Tan (2009) suggested that the brand image is considered to be a strong determinant of brand commitment. A prominent brand can lure the attention of consumers and make them more loyal and committed to the brand (Lee et al., 2011). Moreover, Kumar and Kaushik 
(2020) argue that favorable consumer' perceptions of a brand are likely to enhance consumer's attachment to a brand across product and service categories.

Following the aforementioned theoretical outcomes, this study argues that brand commitment should be viewed as different from brand loyalty and, therefore, should be conceptualized and measured in a way that enables us to capture consumers' emotional feelings and desire to maintain the relationship with a brand (Kumar \& Kaushik, 2020). Because of this, it is also relevant to argue for a possible positive impact of brand image on brand commitment. This study, therefore, proposes that:

H2. Brand image has a positive and direct effect on brand commitment.

Following the above theoretical outcomes by which two hypotheses were formulated, one can theoretically argue that brand image has a positive impact on brand loyalty and brand commitment. Nevertheless, it should be noted that these hypotheses were formulated based on the prior research that placed focus on examining the effect of brand image on brand loyalty and brand commitment in the context of NBs. In this study, we applied the construct of brand image to PLBs, based on the notion that consumers can create strong emotional bonds with PLBs in the same way as they are forming relationships with NBs (Kumar \& Kaushik, 2020; Pourazad et al., 2019). Thus, this study attempts to test the applicability of the brand attachment theory to both NBs and PLBs. Thus, the following hypotheses are formulated:

H3: There are differences in the size of the effect between brand image and brand loyalty among national brands (NBs) and private label brands (PLBs).

H4: There are differences in the size of the effect between brand image and brand commitment among national brand (NBs) and private label brands (PLBs).

\section{Methodology \\ Research setting}

In this study, we placed a focus on brand image for two types of brands, namely NBs and PLBs. Since the majority of previous studies investigated brand image in the context of NBs, the findings cannot be easily generalized to PLBs. To deepen our understanding of the importance of the brand image in building consumer-relationship in PLBs context, it becomes paramount that scholars conduct more research in the context of both NBs and PLBs. Thus, in this study, we selected PLB Lumpi and its NB counterpart Violeta, as one of the leading brands of hygiene products in Bosnia and Herzegovina, Croatia, and Slovenia. Violeta, launched in 2002, is Bosnia and Herzegovina's leading manufacturer of personal and household care products. Through production in Croatia and distribution in Slovenia, Violeta has become the first brand on the West European market in the production of hygienic products. On the other hand, Lumpi is the PLB owned by Mercator, one of the leading regional retailers, encompassing 77 retail stores in Bosnia and Herzegovina. Mercator is a Slovenian multinational retailer, owned by the Croatian company Agrokor, which operates in the Central and Southeast Europe. Private brand Lumpi, owned by the Mercator, is intended for children under the age of ten. The Lumpi line contains a variety of nutritional products, daily care products, clothing, diapers, and a rich accompanying 
program for the youngest. The choice of a product category - a personal care product category (i.e., wet wipes) is based on the following criteria: (1) the product is bought regularly, and thereby, consumers are able to evaluate easily different aspects of the product; (2) the product carries a greater level of consumer involvement and high degree of risk associated with its purchase.

\section{Data collection and sample}

Data were collected using a cross-sectional in-store intercept survey among consumers residing in the city of Sarajevo (Bosnia and Herzegovina). At the exit of the store, undergraduate students with general training in market research stopped to interview customers whom they asked to complete a self-administered questionnaire that took about $15 \mathrm{~min}$. The survey was carried out at eight different stores belonging to the retail chain Mercator. Upon approaching the respondents, the interviewers identified themselves, explained the purpose of the research, and provided respondents with the definition of NBs and PLBs. Interviews were carried out on both weekdays and weekends during the morning and late afternoon/evening hours to reduce possible bias. At the end of fieldwork, a total of 712 usable questionnaires were obtained across two types of brands, 351 usable responses for NB Violeta and 361 usable responses for PLB Lumpi. A detailed breakdown of the sample characteristics, in terms of gender, age, income, education, and the frequency of purchases (PLBs versus NBs), is presented in table 1.

Table 1. Demographic characteristics

\begin{tabular}{lc|lc}
\hline Variable & $\mathbf{\%}$ & Variable & $\mathbf{\%}$ \\
\hline Gender & & Education & \\
Female & 75.3 & High school & 25.9 \\
Male & 24.7 & College or vocational school & 17.4 \\
Age & & Bachelor's degree & 37.2 \\
$\quad$ Under 20 years & 8.2 & Master's degree or higher & 19.5 \\
21-25 years & 27.8 & Brand type & \\
26 - 30 years & 21.5 & National brand - Violeta & 49.3 \\
$31-35$ years & 17.1 & Private label brand - Lumpi & 50.7 \\
$36-40$ years & 15.8 & Purchase frequency & \\
40 + & 9.6 & Seldom & 19.3 \\
Income & & Sometimes & 35.1 \\
Under BAM 1,000 & 21.7 & Often & 45.6 \\
BAM 1,001 - 1,500 & 40.3 & & \\
BAM 1,5001 - 2,000 & 28.1 & & \\
BAM 2,000 + & 9.9 & & \\
\hline
\end{tabular}

Source: Author's own results

The sample was moderately distorted toward women, approximately 3:1. This skewed gender distribution is consistent with the assumption that women are typically more responsible for household shopping than their male counterparts (Beneke, 2013).

\section{Research instrument}

A structured questionnaire was designed to test hypothesized relationships between the constructs of the interest. The items were extracted from the established measurement scales. The brand image scale assessed consumers' perceptions of the brand image based on the three components: functional image, affective image, and reputation. Initial and final 
brand image scales were adapted from Martínez Salinas and Pina Pérez (2009). Insight into previous brand loyalty research indicates the dominant use of attitude-based loyalty (e.g., Pappu et al., 2005; Yoo \& Donthu, 2001; Yoo et al., 2000). Following previous research, the operationalization of brand loyalty in the present study is also based on measuring loyalty to a particular brand based on attitude toward a brand. For measuring brand loyalty, we adopted three items scale developed by Yoo et al. (2000) and Yoo and Donthu (2001). Finally, brand commitment is viewed as two-dimensional construct encompassing: affective and calculative (continuance) commitment (Fullerton, 2003). Thus, brand commitment was assessed using a scale employed by Fullerton (2003). All involved constructs were measured using a seven-point Likert scale, ranging from 1 „strongly disagree" to 7 „strongly agree".

\section{Results}

This section presents the analysis of data obtained from the field study and provides the interpretation of the main findings. Data analysis proceeded in three phases. First, the internal reliability of responses in multi-item scales was evaluated by determining Cronbach's alpha coefficient and item-to total correlations (Hair et al., 2010). The statistical package Mplus version 6.0 was used for the data analysis. The results revealed that scales measuring brand image (BI), brand loyalty (BL), and brand commitment (BC) are reliable with the present data (table 2). Also, the analysis revealed Cronbach's alpha to be less than the recommended value of 0.7 (0.527) for one item belonging to the affective commitment: "I feel like part of a family as a customer of brand X"(ac1). So, this item is excluded from further research.

Table 2. Scaling and measurement properties

\begin{tabular}{|c|c|c|c|c|}
\hline Constructs & Code & Dimensions and manifest variables & $\lambda$ & $\begin{array}{l}\text { Stand. } \\
\text { error }\end{array}$ \\
\hline \multirow{3}{*}{$\begin{array}{l}\text { Functional } \\
\text { image (FI) } \\
\alpha=0.925\end{array}$} & fi1 & The product has a high quality. & 0.910 & \\
\hline & fi2 & $\begin{array}{l}\text { The product has better characteristics than } \\
\text { competitors'. }\end{array}$ & 0.921 & 0.026 \\
\hline & fi3 & $\begin{array}{l}\text { The products of the competitors are usually } \\
\text { cheaper. }\end{array}$ & 0.883 & 0.033 \\
\hline \multirow{3}{*}{$\begin{array}{l}\text { Affective } \\
\text { image (AI) } \\
\alpha=0.929\end{array}$} & ai1 & The brand is nice. & 0.910 & \\
\hline & ai2 & $\begin{array}{l}\text { The brand has a personality that distinguishes itself } \\
\text { from competitors. }\end{array}$ & 0.964 & 0.023 \\
\hline & ai3 & It's a brand that doesn't disappoint its customers. & 0.841 & 0.027 \\
\hline \multirow{2}{*}{$\begin{array}{l}\text { Reputation } \\
\text { (RE) } \\
\alpha=0.873 \\
\end{array}$} & re1 & It's one of the best brands in the sector. & 0.860 & \\
\hline & re2 & The brand is much consolidated in the market. & 0.904 & 0.032 \\
\hline \multirow{4}{*}{$\begin{array}{l}\text { Affective } \\
\text { commitment } \\
\text { (AC) } \\
\alpha=0.854\end{array}$} & ac1 & I feel like part of a family as a customer of brand X. & 0.550 & \\
\hline & ac2 & I feel emotionally attached to brand X. & 0.810 & 0.148 \\
\hline & ac3 & $\begin{array}{l}\text { Brand X has a great deal of personal meaning for } \\
\text { me. }\end{array}$ & 0.826 & 0.130 \\
\hline & ac4 & I feel a strong sense of identification with brand X & 0.916 & 0.139 \\
\hline \multirow{2}{*}{$\begin{array}{l}\text { Continuance } \\
\text { commitment } \\
\text { (CC) } \\
\alpha=0.942 \\
\end{array}$} & cc1 & $\begin{array}{l}\text { It would be very hard for me to switch away from } \\
\text { brand X right now, even if I wanted to. }\end{array}$ & 0.897 & \\
\hline & cc2 & $\begin{array}{l}\text { My life would be disrupted if I switched away from } \\
\text { brand X. }\end{array}$ & 0.911 & 0.033 \\
\hline
\end{tabular}




\begin{tabular}{|c|c|c|c|c|}
\hline & $\mathrm{cc} 3$ & $\begin{array}{l}\text { It would be too costly for me to switch from brand X } \\
\text { right now. }\end{array}$ & 0.892 & 0.030 \\
\hline & $\operatorname{cc} 4$ & $\begin{array}{l}\text { Right now, staying with brand } \mathrm{X} \text { is as much a matter } \\
\text { of necessity as it is of choice }\end{array}$ & 0.892 & 0.031 \\
\hline \multirow{3}{*}{$\begin{array}{l}\text { Brand loyalty } \\
\text { (BL) } \\
\alpha=0.842\end{array}$} & bl1 & I consider myself to be loyal to brand $\mathrm{X}$ & 0.796 & \\
\hline & bl2 & Brand X would be my first choice. & 0.830 & 0.050 \\
\hline & bl3 & $\begin{array}{l}\text { I will not buy other brands if brand } \mathrm{X} \text { is available at } \\
\text { the store. }\end{array}$ & 0.968 & 0.046 \\
\hline \multirow{3}{*}{$\begin{array}{l}\text { Brand image } \\
\text { (BI) }\end{array}$} & FI & Functional image & 0.753 & \\
\hline & AI & Affective image & 0.822 & 0.125 \\
\hline & $\mathrm{RE}$ & Reputation & 0.976 & 0.095 \\
\hline \multirow{2}{*}{$\begin{array}{l}\text { Brand } \\
\text { commitment } \\
\text { (BC) }\end{array}$} & $\mathrm{AC}$ & Quality PB image & 0.724 & \\
\hline & $\mathrm{CC}$ & Affective PB image & 0.858 & 0.201 \\
\hline
\end{tabular}

Source: Author's own results

Second, the structural equation modeling (SEM) technique to examine hypotheses in the proposed model was applied. Following the methodological suggestions of Anderson and Gerbing (1988), the two-step approach was employed to assess the structural equation model. The first step includes the evaluation of the measurement model, while the second step allows us to test the structural relationships (hypotheses) among the latent constructs. The two-step approach eliminates the interaction between the measurement and structural models and re-specification errors (Hair et al., 2010).

Confirmatory factor analysis (CFA) was used to assess the reliability, convergent validity, and discriminant validity of constructs in the proposed model. The measurement model was estimated using the maximum-likelihood method (MLM), and the model fit was tested using several fit indices. Although it is challenging to determine the cut-off value for a particular fit index, it is important to provide some criteria for the evaluation of model fit. Therefore, we used the following criteria: Root Mean Square Error of Approximation (RMSEA) value less than 0.10 (Maccallum et al., 1996), Standardized Root Mean Squared Residual (SRMR) value less than 0.08 (Hu \& Bentler, 1999), a normed chi-square value ( $\chi 2$ /df) less than 5.0 (Scumacker \& Lomax, 2004), and the Comparative Fit Index (CFI) and the Tucker-Lewis index (TLI) greater than 0.9 (Hair et al. 2010). According to the model evaluation criteria suggested in the prior discussion, the overall fit of the measurement model to data was acceptable: $\chi 2=407.525(\mathrm{p}<0.001) ; \chi 2 / \mathrm{df}=3.21$; RMSEA $=0.056$, SRMR $=0.0329 ; \mathrm{CFI}=0.976 ; \mathrm{TLI}=0.971 ; \mathrm{GFI}=0.939 ; \mathrm{AGFI}=0.917$.

We then assessed the construct's internal consistency and validity. All constructs were found to be highly consistent and reliable as their composite reliability (CR) scores were above the required cut-off value of 0.7 (Bagozzi \& Yi, 2012). As suggested by Hair et al. (2010), convergent validity is fulfilled if the standardized factor loading is higher than 0.5, and the average variance extracted (AVE) is above 0.5. As shown in Table 2, the standardized factor loading of items (manifest variables) and first-order constructs ranged from 0.501 to 0.981 , and all were statistically significant $(\mathrm{p}<0.001)$. The average variance extracted of the three latent constructs (BL, BI, and BC) was 0.753, 0.731, and 0.625, respectively. These findings suggest that convergent validity is satisfied. Discriminant validity was evaluated by comparing the square root AVE of each construct to its correlations with other constructs (Fornell \& Larcker, 1981). The results showed that the 
discriminant validity of constructs is supported as the square root AVE of each construct is higher than the correlations between that construct and any other construct in the model. Table 3 shows CR, AVE, square root AVE, and correlation values, supporting reliability, convergent, and discriminant validity of constructs.

Table 3. Reliability, convergent and discriminant validity of constructs

\begin{tabular}{lll|llc}
\hline & \multicolumn{3}{c|}{$\begin{array}{c}\text { Composite reliability and } \\
\text { convergent validity }\end{array}$} & \multicolumn{3}{c}{ Discriminant validity } \\
\hline Construct & CR & AVE & BL & BI & BC \\
\hline Brand loyalty (BL) & 0.901 & 0.753 & $\mathbf{0 . 8 6 8}^{\mathbf{a}}$ & & \\
Brand image (BI) & 0.890 & 0.731 & 0.708 & $\mathbf{0 . 8 5 5}$ & \\
Brand commitment (BC) & 0.767 & 0.625 & 0.411 & 0.459 & $\mathbf{0 . 7 9 1}$ \\
\hline
\end{tabular}

Note: a Square root AVE values are in diagonals (bold) and correlations (r) are off-diagonal values

Source: Author's own results

\section{Structural model and hypotheses testing}

Subsequent structural equation modeling (SEM) analyses were conducted to support the proposed model and to test the hypotheses. The fitting indices of the structural model are as follows: $\chi^{2}=415.140(\mathrm{p}<0.001) ; \chi^{2} / \mathrm{df}=3.240 ;$ RMSEA $=0.056$, SRMR $=0.0381 ; \mathrm{CFI}=$ 0.975 ; $\mathrm{TLI}=0.970 ; \mathrm{GFI}=0.938 ; \mathrm{AGFI}=0.917$. In comparison with values suggested in the prior discussion, findings demonstrate that the model's fit is satisfactory. Thus, it was deemed appropriate to test the hypothesized paths (table 4).

Table 4. Hypotheses testing

\begin{tabular}{llll}
\hline $\begin{array}{l}\text { Causal relationship (standardized } \\
\text { coefficient) }\end{array}$ & Total sample & National brand & Private label brand \\
\hline Brand image $\rightarrow$ Brand loyalty & $\beta=0.713^{* * *}$ & $\beta_{\mathrm{NBs}}=0.680^{* * *}$ & $\beta_{\mathrm{PLBS}}=0.629^{* * *}$ \\
\hline Brand image $\rightarrow$ Brand commitment & $\beta=0.475^{* * *}$ & $\beta_{\mathrm{NBs}}=0.431^{* * *}$ & $\beta_{\mathrm{PLBs}}=0.363^{* * *}$ \\
\hline Notes: ${ }^{* * *} \mathrm{p}<0.001{ }^{* *} \mathrm{p}<0.01 ;^{*} \mathrm{p}<0.05$ & & & \\
\hline & & \multicolumn{2}{c}{ Source: Author's own results }
\end{tabular}

As predicted by hypothesis $\mathrm{H} 1$, a positive relationship between brand image and brand loyalty was supported for both NBs and PLBs $(\beta=0.713 ; \mathrm{p}<0.001)$. The brand image was also found to have a statistically significant positive influence on brand commitment for both NBs and PLBs $(\beta=0.475 ; \mathrm{p}<0.001)$, providing support for hypothesis $\mathrm{H} 2$. Furthermore, we found that our model explains $50.9 \%$ of brand loyalty and $22.5 \%$ of brand commitment, suggesting that the structural model exhibits an adequate level of explanatory power. However, it is worth noting that only $22.5 \%$ of the variance of brand commitment was explained by brand image, indicating that bonding between a consumer and a brand is just partially explained by consumers' cognitive and affective assessments of a brand.

The second objective of the current research was to analyze the influence of the type of a brand (NBs vs. PLBs) on the relationship between brand image and brand loyalty, as well as brand image and brand commitment. Therefore, group comparisons were made between NBs and PLBs, using structural equation modeling. The $\chi^{2}$ difference test indicated that there is a statistically significant difference between the NBs and PLBs $\left(\chi^{2}=97.493\right.$, 
$\mathrm{df}=17, \mathrm{p}<0.001)$. Concerning the relationship between brand image and brand loyalty, it was found that NBs image positively affects brand loyalty $\left(\beta_{\mathrm{NBs}}=0.680 ; \mathrm{p}<0.001\right)$, just as PLBs image influences brand loyalty $\left(\beta_{\text {PLBs }}=0.629 ; \mathrm{p}<0.001\right)$. Thus, our study reveals that the effect of brand image on brand loyalty is not significantly different for NBs and PLBs $\left(\chi^{2}\right.$ $=0.008, \mathrm{df}=1, \mathrm{p}<0.930$ ). Thus, the hypothesis $\mathrm{H} 3$ is not supported. In particular, the findings of this study are not in line with previous research, which showed that relationship between brand loyalty and image of PLBs is negative, suggesting that consumers are less loyal towards PLBs and instead tend to show stronger variety-seeking and switching tendencies (Garretson et al., 2002). Although NBs have particularly strong branding equity and, thus, they are able to evoke favorable brand associations, our findings suggest that brand equity and positioning are also essential aspects of PLBs market success. Therefore, our finding reinforces the supposition that PLBs have positioned themselves as brands that offer the value for money, and that price per se is not then the key driver of loyalty toward PLBs (Beneke \& Carter, 2015; Miquel-Romero et al., 2017). Overall, our findings suggest that brand image is an essential driver of brand loyalty for both NBs and PLBs. In line with this notion, the findings indicate that a favorable brand image enhances the likeliness of consumer's attachment to the brand bor both NBs and PLBs. In terms of H4, results suggest that the brand image-brand commitment link is significantly different between NBs and PLBs $\left(\chi^{2}=6.421, \mathrm{df}=1, \mathrm{p}<0.011\right)$. Therefore, the fourth hypothesis (H4) within this study is supported. Although the brand image is positively associated with consumer's cognitive and affective commitment to a brand for both NBs and PLBs, the brand image contributes more to the formation of consumer's commitment to NBs than to the consumer's commitment to PLBs. This finding is consistent with research highlighting the important role of mental accessibility in choice (Trinh \& Dawes, 2020). Since NBs evoke greater awareness among consumers and consumers are more familiar with such brands, NBs seem to enjoy a greater advantage than PLBs (Liu et al., 2018).

\section{Conclusion}

This research explored the possible effect of brand image on consumer-based relationship constructs, namely brand loyalty and brand commitment. Furthermore, it evaluates these relationships in the light of customer behavior towards NBs and PLBs in the category of personal hygiene products. Additionally, the current study attempts to explore the brand image-consumer-brand relationship link for NBs and PLBs in the so-called PBLs developing markets where PB market penetration rate is significantly lower compared to that in mature European and U.S. markets. Following outcomes from the literature review and conceptual frameworks relating to brand image, brand loyalty, and brand commitment, four hypotheses were formulated and empirically tested.

Findings obtained in previous studies indicate that brand image might have important consumer implications, including a positive impact on perceived quality, satisfaction, loyalty, and commitment (e.g., Kumar \& Kaushik, 2020; Ogba \& Tan, 2009; Song et al., 2019). However, previous studies placed focus on exploring the antecedents of brand image in the context of NBs. Only a few studies examined the link between brand image and consumer-based relationship constructs (brand loyalty brand commitment) in the context of PLBs. Therefore, in the present study, we applied the construct of brand image to PLBs, based on the premise that consumers can build strong emotional ties with PLBs similarly as 
they are forming relationships with NBs. The main finding of this study is that brand image plays an essential role in building brand loyalty and commitment both for NBs as well as PLBs.

Regarding the first hypothesis, namely H1, "Brand image has a positive and direct effect on brand loyalty" our findings suggest that brand image (based on the three components: functional image, affective image, and reputation) have a significant positive influence on brand loyalty for both types of brands (NBs and PLBs). These results suggest that creating and building a positive brand image in the minds of consumers can be of crucial importance to the market success of both NBs and PLBs. These findings indicate that the more a particular brand is perceived to be better, in terms of the functional, emotional image, and overall reputation, it enjoys the advantage over other brands. Consequently, a favorable brand image will enhance brand loyalty, regardless of whether it's a well-known NB or a PLB owned and sold by a particular retailer. A similar conclusion can be drawn concerning the second research hypothesis, respectively $\mathrm{H} 2$, "Brand image has a positive and direct effect on brand commitment". The more the brand image is perceived as favorable by consumers, the higher the brand commitment will be (taking into account affective and calculative/continuance commitment), for both NBs and PLBs.

Regarding the hypotheses $\mathrm{H} 3$ and $\mathrm{H} 4$, which are related to the issue of analyzing differences between NBs and PLBs, the obtained results confirm that there is a statistically significant difference in the effect of the brand image on brand-relationship constructs among NBs and PLBs. However, this distinction between NBs and PLBs is related to the brand image-brand commitment link. Our findings suggest that brand image has a greater influence on brand loyalty and brand commitment for NBs than for PLBs. This finding can be explained by the fact that NBs are widely distributed and advertised brands, while PLBs are exclusively tied to one retailer which owns such brands.

The present study deepens our understanding of consumer-brand relationships for different types of brands - NBs versus PLBs). Given a lack of rigorous empirical research in the area of private branding in PLBs developing markets and non-Western world countries, the current research enhances the external validity (generalizability) of previous work. Also, this study enriches the existing body of knowledge in the branding field by revealing that brand image is a driver of brand loyalty and brand commitment for both NBs and PLBs.

The present study provides marketing managers of NBs and PLBs some insights into how to spur brand loyalty and commitment. In summary, the current research has reinforced the notion that management of brand image is worthwhile for both manufacturers and retailers since favorable brand image leads to positive consumer responses (i.e., brand loyalty and brand commitment). Bearing in mind that transfer from manufacturer brands to PLBs increases the consumer's trustworthiness toward PLBs (Konuk, 2019), the retailers should collaborate with well-known and top-tier manufacturers. This way, the retailers will create a trustworthy image for their PLBs and increase consumer loyalty and commitment to PLBs. Since PLBs are traditionally positioned as low-quality and high-risk brands, retailers are advised to use extrinsic cues (e.g., packaging) to infer the quality of PLBs. To build consumer-brand relationships (brand loyalty and brand commitment), the manufacturers and retailers should develop a lovemarks' nurturing strategy. As suggested by Roberts (2004), lovemarks can build consumer-brand relationships, which are primarily reflected in the permanent positive emotions to a brand or repetitive purchases. To this end, manufacturers and retailers 
should improve positive cognitive and emotional associations with NBs and PLBs by using different types of storytelling and developing social media brand communities. Through these methods, manufacturers and retailers will form strong emotional bonds between consumers and brands.

\section{Limitations and recommendations for further research}

Although the present study contributes to the branding literature, there are some limitations worth acknowledging. First, these include issues with the data collection, which are collected exclusively in the retailer's stores located in the city of Sarajevo, and for only one product category. This constraint may have a direct impact on a possible generalization of the research outcomes. Future studies should try to expand the domain of this research in terms of the geographical coverage and product category. Second, it is possible that the frequency with which consumers use a brand, as well as how long they have been using it, affect the image for that brand. Since this issue was not controlled in the current study, it should be addressed in future research. Finally, the relation between brand image and brand loyalty and commitment may be moderated by contextual variables (e.g., type of product, the stage of market development, and the number of competing brands in the market). Hence, future studies aiming to address these issues are welcomed.

\section{References}

Aaker, D. A. (1991). Managing Brand Equity. New York, NY: The Free Press.

Aaker, D. A. (1996). Measuring brand equity across products and markets. California Management Review, 38(3), 102-120.

Aggarwal, P. (2004). The effects of brand relationship norms on consumer attitudes and behavior. Journal of Consumer Research, 31 (1), 87-101.

Akcura, M., Sinapuelas, I. and Wang, H. (2019). Effects of multitier private labels on marketing national brands. Journal of Product \& Brand Management, 28 (3), 391407.

Allen, N. J., \& Meyer, J. P. (1990). The measurement and antecedents of affective, continuance and normative commitment to the organization. Journal of Occupational Psychology, 63(1), 1-17.

Anderson, J. C., \& Gerbing, D. W. (1988). Structural equation modelling in practice: a review and recommended two-step approach. Psychological Bulletin, 103(3), 411-423.

Bagozzi, R. P., \& Yi, Y. (2012). Specification, evaluation, and interpretation of structural equation models. Journal of the Academy of Marketing Science, 40(1), 8-34.

Baltas, G., \& Argouslidis, P. C. (2007). Consumer characteristics and demand for store brands. International Journal of Retail \& Distribution Management, 35(5), 328-341.

Bansal, H .S., Irving, P. G., \& Taylor, S. F. (2004). A three-component model of customer commitment to service providers. Journal of the Academy of Marketing Science, $32(3), 234-250$.

Beneke, J. (2013). The influence of perceived product quality, relative price and risk on customer value and willingness to buy: a study of private label merchandise. Journal of Product \& Brand Management, 22(3), 218-228.

Bilgihan, A. (2016). Gen Y customer loyalty in online shopping: an integrated model of trust, user experience and branding. Computers in Human Behavior, 61(C), 103-113. 
Bneke, J., \& Carter, S. (2015). The development of a consumer value proposition of private label brands and the application thereof in a South African retail context. Journal of Retailing and Consumer Services, 25, 22-35.

Bozzo, C., Merunka, D., \& Moulines, J. K. (2003). Fidelite et comportement d'achat: ne pas se fier aux apparences. Decisions Marketing, 32(4), 9-17.

Calvo-Porral, C., Martinez-Fernández, V. A., Juanatey-Boga, O., \& ve Lévy-Mangín, J. P. (2013). What matters to store Brand Equity? An approach to Spanish large retailing in a downturn context. Investigaciones Europeas de Direccion y Economia de la Empresa, 19(3), 136-146.

Cuneo, A., Milberg, S. J., Alarcon-del-Amo, M. del C., \& Lopez-Belbeze, P. (2019). Private label and manufacturer brand choice in a new competitive reality: Strategic directions and the future of brands. European Management Journal, 37(1), 117-128.

Day, G.A. (1969). Buyer Attitudes and Brand Choice Behavior. New York, NY: The Free Press.

Dick, A. S., \& Basu, K. (1994). Customer loyalty: Toward an integrated conceptual framework. Journal of the Academy of Marketing Science, 22(2), 99-113.

Elbedweihy, A., Jayawardhena, C., Elsharnouby, M. H., \& Elsharnouby, T. H. (2016). Customer relationship building: The role of brand attractiveness and consumerbrand identification. Journal of Business Research, 69, 2901-2910.

Ferreira, P., Rodrigues, P., and Rodrigues, P. (2019). Brand love as mediator of the brand experience-satisfaction-loyalty relationship in a retail fashion brand. Management \& Marketing: Challenges for the Knowledge Society, 14(3), 278-291.

Fornell, C. \& Larcker, D. F. (1981). Structural equation models with unobservable variables and measurement error: algebra and statistics. Journal of Marketing Research, 18(3), 382-388.

Fournier, S. (1998). Consumers and their brands: developing relationship theory in consumer research. Journal of Consumer Research, 24(4), 343-373.

Fullerton, G. (2003). When does commitment lead to loyalty? Journal of Service Research, $5(4), 333-344$.

Garretson, J.A., Fisher, D., \& Burton, S. (2002). Antecedents of private label attitude and national brand promotion attitude: similarities and differences, Journal of Retailing, 78(2), 91-99.

Giovanis, A. (2016). Consumer-brand relationships' development in the mobile internet market: evidence from an extended relationship commitment paradigm. Journal of Product \& Brand Management, 25(6), 568-585.

Giovanis, A. N., \& Athanasopoulou, P. (2018). Consumer-brand relationships and brand loyalty in technology-mediated services. Journal of Retailing and Consumer Services, 40, 287-294.

Gounaris, S., \& Stathakopoulos, V. (2004). Antecedents and consequences of brand loyalty: An empirical study. Journal of Brand Management, 11(4), 283-307.

Grace, D., Ross, M., \& King, C. (2020). Brand fidelity: Scale development and validation. Journal of Retailing and Consumer Services, 52, 101908. Retrieved from: doi: 10.1016/j.jretconser.2019.101908.

Gundlach, G. T., Achrol, R. S. \& Mentzer, J. T. (1995). The structure of commitment in exchange. Journal of Marketing, 59(1), 78-92.

Hair, J. F., Black, W. C., Babin, B. J., \& Anderson, R .E. (2010). Multivariate Data Analysis (7th ed.). Upper Saddle River, NJ: Prentice Hall. 
Hoskins, J. D. (2016). Offering value and capturing surplus: A strategy for private label sales in a new customer loyalty building scenario. Journal of Retailing and Consumer Services, 28, 274-280.

Hsieh, M., Pan, S., \& Setiono, R. (2004). Product-, corporate-, and country-image dimensions and purchase behavior: a multicountry analysis. Journal of the Academy of Marketing Science, 32(3), 251-270.

Hu, L., \& Bentler, P.M. (1999). Cutoff criteria for fit indexes in covariance structure analysis: Conventional criteria versus new alternatives. Structural Equation Modeling: A Multidisciplinary Journal, 6(1), 1-55.

Iglesias, O., Singh, J., \& Batista-Foguet, J.M. (2011) The role of brand experience and affective commitment in determining brand loyalty. Journal of Brand Management, 18(8), 570-582.

Ipek, I., Aşkin, N., \& Ilter, B. (2016). Private label usage and store loyalty: The moderating impact of shopping value. Journal of Retailing and Consumer Services, 31, $72-79$

Jing, Z., Pitsaphol, C. \& Shabbir, R. (2014). The influence of brand awareness, brand image, and perceived quality on brand loyalty. Interdisciplinary Journal of Contemporary Research in Business, 5(12),13-19.

Juhl, H. J., Esbjerg, L., Grunert, K. G., Bech-Larsen, T., \& Brunsø, K. (2006). The fight between store brands and national brands-What's the score?. Journal of Retailing and Consumer Services, 13(5), 331-338.

Keller, K. (1993). Conceptualizing, measuring, and managing customer-based equity. Journal of Marketing, 57(1), 1-22.

Konuk, F. A. (2019). Trust transfer from manufacturer to private label brand: The moderating role of grocery store format. Journal of Retailing and Consumer Services, 27, 101955. Retrieved from: doi: 10.1016/j.jretconser.2019.101955.

Kumar, N., \& Steenkamp, J. E. M. (2007). Private Label Strategy: How to Meet the Store Brand Challenge. Boston, MA: Harvard Business School Press.

Kumar, V., \& Kaushik, A. K. (2020). Building consumer-brand relationships through brand experience and brand identification. Journal of Strategic Marketing, 28(1), 39-59.

Lee, H. M., Lee, C. C., \& Wu, C. (2011). Brand image strategy affects brand equity after M\&A. European Jurnal of Marketing, 45(8), 1091-1111.

Liu, R. L., Sprott, D. E., Spangenberg, E. R., Czellar, S., \& Voss, K. E. (2018). Consumer preference for national vs. private brands: The influence of brand engagement and self-concept threat. Journal of Retailing and Consumer Services, 41, 90-100.

Maccallum, R. C., Browne, M. W., \& Sugawara, H.M. (1996). Power analysis and determination of sample size for covariance structure modeling of fit involving a particular measure of model. Psychological Methods, 13(2), 130-149.

Manzur, E., Olavarrieta, S., Hidalgo, P., Farías, P., \& Uribe, R. (2011). Store brand and national brand promotion attitudes antecedents. Journal of Business Research, 64(3), 286-291.

Martínez Salinas, E., \& Pina Pérez, J. M. (2009) Modeling the brand extensions' influence on brand image. Journal of Business Research, 62(1), 50-60.

Miquel-Romero, M. J., Caplliure-Giner, E. M., \& Adame-Sánchez, C. (2014). Relationship marketing management: Its importance in private label extension. Journal of Business Research, 67(5), 667-672 
Moorman, C., Zaltman, G., \& Deshpande, R. (1992). Relationships between providers and users of market research: The dynamics of trust within and between organizations. Journal of Marketing Research, 29(3), 314-328.

Morgan, R.M., \& Hunt, S.D. (1994). The commitment-trust theory of Relationship Marketing. Journal of Marketing, 58(3), 20-38.

Nyadzayo, M. W., \& Khajehzadeh, S. (2016). The antecedents of customer loyalty: A moderated mediation model of customer relationship management quality and brand image. Journal of Retailing and Consumer Services, 30, 262-270.

Ogba, I. E., \& Tan, Z. (2009). Exploring the impact of brand image on customer loyalty and commitment in China. Journal of Technology Management in China, 4(2), 132-144.

Pappu, R., Quester, P. G., \& Cooksey, R. W. (2005). Consumer-based brand equity: improving the measurement - empirical evidence. Journal of Product and Brand Management, $14(3), 143-154$.

Pourazad, N., Stocchi, L., \& Pare, V. (2019). Brand attribute associations, emotional consumer-brand relationship and evaluation of brand extensions. Australasian Marketing Journal, 27(4), 249-260.

Roberts, K. (2004). Lovemarks: The Future Beyond Brands. Reed, Auckland.

Schumacker, R. E., \& Lomax, R. G. (2004). A beginner's guide to structural equation modeling ( $2^{\text {nd }}$ ed.). Mahwah, NJ: Lawrence Erlbaum Associates Publishers.

Sebri, M., \& Zaccour, G. (2017). Cross-country differences in private-label success: An exploratory approach. Journal of Business Research, 80, 116-126.

Shukla, P., Banerjee, M., \& Singh, J. (2016). Customer commitment to luxury brands: Antecedents and consequences. Journal of Business Research, 69(1), 323-331.

Song, H., Wang, J., \& Han, H. (2019). Effect of image, satisfaction, trust, love, and respect on loyalty formation for name-brand coffee shops. International Journal of Hospitality Management, 79, 50-59.

Sung, Y. \& Choi, S.M. (2010). „I Won't Leave You Although You Disappoint Me”: The interplay between aatisfaction, investment, and alternatives in determining consumer-brand relationship commitment. Psychology \& Marketing, 27(11), 10501074.

Trinh, G., \& Dawes, J. (2020). A comparison of brand loyalty between on the go and takehome consumption purchases. Journal of Retailing and Consumer Services, 53, 101968. In Press. doi: 10.1016/j.jretconser.2019.101968.

Wang, J. J., Torelli, C. J., \& Lalwani, A. K. (2020). The interactive effect of power distance belief and consumers' status on preference for national (vs. private-label) brands. Journal of Business Research, 107, 1-12.

Yoo, B. \& Donthu, N. (2001). Developing and Validating a Multidimensional ConsumerBased Brand Equity Scale. Journal of Business Research, 52(1), 1-14.

Yoo, B., Donthu, N. \& Lee, S. (2000). An examination of selected marketing mix elements and brand equity. Journal of the Academy of Marketing Science, 28(2), 195-211. 